\title{
AN INVESTIGATION ON THE USE OF BACILLUS SUBTILIS HU58 IN CEMENT MORTAR
}

\author{
Nguyen Ngoc Tri Huynh ${ }^{1}$ and Nguyen Khanh Son ${ }^{2}$ \\ ${ }^{1,2}$ Faculty of Materials Engineering, Ho Chi Minh City University of Technology (HCMUT) \\ Ho Chi Minh City, Vietnam, e-mail: ksnguyen@hcmut.edu.vn
}

Received Date: February 16, 2014

\begin{abstract}
Literature studies reveal the fact that incorporating bacteria into cement matrix could generate the formation of precipitated product of calcium carbonate. In this work, a new type of microorganism Bacillus subtilis HU58 was used as mixing component in formulating mortar sample of Portland cement and the effectiveness of self-healing character after 1 year of curing time was observed. Results showed the consequence in the enhancement of both compressive and flexural strengths of bacteria-modified mortar while comparing to a controlled mortar: $60 \mathrm{MPa}>56 \mathrm{MPa}$ (in compression) and $11 \mathrm{MPa}>9 \mathrm{MPa}$ (in flexion). Furthermore, those pre-existing artificial cracks $1 \mathrm{~mm}$ in width of the prismatic mortar 40x40x160mm filled up partially (self-healing) by mineral glue.
\end{abstract}

Keywords: Bacillus subtilis HU58, Bacteria-modified mortar, Precipitated calcium carbonate, Self-healing material

\section{Introduction}

In general, research on bio-cement/concrete material or bacteria-modified cement is an initiative to develop a kind of "living" smart materials for sustainable construction. The biological approach in self-healing materials takes inspiration from the natural phenomenon of bone regeneration or bio-calcification process. Such precipitated products of carbonate calcium act as natural glue to heal open cracks at meso/micro scale that are generated in the matrix of hydrated cementitious product. Recently, self-healing concrete material based on bacteria metabolism has gained much attention from researchers around the world because of its potential to improve durability property of concrete structure. In comparison with other techniques based on chemical and natural reaction, the bio-inspired approach shows more advantage in terms of its effectiveness and environment-friendly[1]. Bio-mineralization process of bacteria metabolism would be activated gradually while existing three components of live microorganism, humidity of water penetration and nutrient in an empty space of microporous hardened cement. Current research trends tend to explore different types of bacteria in laboratory study and technology development of this lab proven concept in concrete elements[1].

Research of S. Ghosh et al. in 2009 showed that some types of soil bacteria contribute to increase the $\mathrm{Ca} / \mathrm{Si}$ ratio of calcium silicate hydrate $(\mathrm{C}-\mathrm{S}-\mathrm{H})$ product by incorporating well-crystallized minerals[2]. In general, those bacteria must be active in high alkaline medium of hydrated cement and feed by selective intake of nutrients dissolved in water.

For example, the combination of Bacillus DSM 6037 and Bacillus pseudofirmuscohnii DSM 8715 with the nutrient solution of calcium lactate forms crystalline products of calcite[3]. 
These calcites could also be produced by Bacillus pasteurii and the nutrient medium of urea and calcium chloride $\left(\mathrm{CaCl}_{2}\right)[4]$. Al-Thawadi et al. and P. Ghosh et al. reviewed the mechanism of bio-mineralization in one of their relevant publications [5]. Compressive strength of bacteria modified cement mortar at 28 days of curing time was higher than the controlled mortar (by 25\%)in another study[6].

In an article published in 2014, the preliminary result of calcium carbonate precipitation in cement paste that contains microbial Bacillus subtilis HU58 was tested[7]. In the rest of this paper, we focus on investigating the effects of precipitated product on the long-term behavior, up to 1 year of cement mortar sample. Both results of physiomechanical property and other analytical analysis of materials will be discussed in this study.

\section{Materials and Method}

First, bacterial solution was prepared from urea, $\mathrm{CaCl}_{2}$, and Bacillus subtilis HU58 with proportional mixture as given in Table 1. The solution was then stored in Petri dish for bacterial culture in laboratory condition during different incubation period of $0.5,1,2,4$, 16, 32, 64 and 128 hours. In addition, prepared samples were characterized via X-ray diffraction (XRD, using D8-Advance Diffractometer-Bruker) with a CuK $\alpha$ source operating at $40 \mathrm{kV}$ and $40 \mathrm{~mA}$ for phase analysis and Scanning Electron Microscopy (SEM, FE SEM S4800-Hitachi) for microstructural observation. Crystalline morphology was also observed under Transmission Electron Microscopy (TEM, using JEM 1400Plus-Jeol). The Fourier transform spectroscopy (FTIR, using NICOLET NEXUS FTIR-470-Thermo Electron Corporation) was also used to demonstrate the calcite precipitation in bacterial solution.

Table 1. Proportional Mixture of Bacterial Solution (1.26\% by Mass of Cement in Bacteria-modified Mortar Sample)

\begin{tabular}{llllll} 
& $\begin{array}{l}\text { Bacillus } \\
\text { SubtilisHU58 }\end{array}$ & Urea & $\mathbf{C a C l}_{2 . \mathbf{H}_{2} \mathbf{O}}$ & Nutrient Broth & Total \\
\hline \%wt. & 0.49 & 0.44 & 0.22 & 0.11 & 1.26 \\
\hline
\end{tabular}

We used Portland cement PC40, graded standard sand, tap water to formulate controlled mortar. An amount of $1.26 \%$ by mass of the above bacterial solution was added in bacteria modified cement mortar. Two series of prismatic $40 \times 40 \times 160 \mathrm{~mm}$ samples (bacterial and controlled mortar) were demolded and cured in water tank for 1, 3, 7, 28, 60, 90 days and 1 year before going through test of mechanical resistance according to TCVN 6016:2011 (ISO 679:2009)[8] (cement: standards and: tap water = 1:3:0,5). Relating to the test of self-healing ability, 14 age day bacteria-modified mortar was broken into two parts and then, kept in the right position to submerge in water tank. We examined the state of cracked samples after 28 days of curing time and also we had recourse to analysis technique the healing glue material.

\section{Results}

The result of XRD patterns, superposed for comparison in Figure 1 reveals major peaks $2 \theta$ = 29.5; 47.5; $48.5^{\circ}$ of crystalline product of calcite(ICDD \# 05-0586). We also noted that intensity and peak sharpness at $2 \theta=29.5^{\circ}$ appear to be increasing over incubation period of bacterial culture (1 -128 hours). That means, due to the process of bio-mineralization, calcite peaks gradually increase in the resulted bacterial solution. 


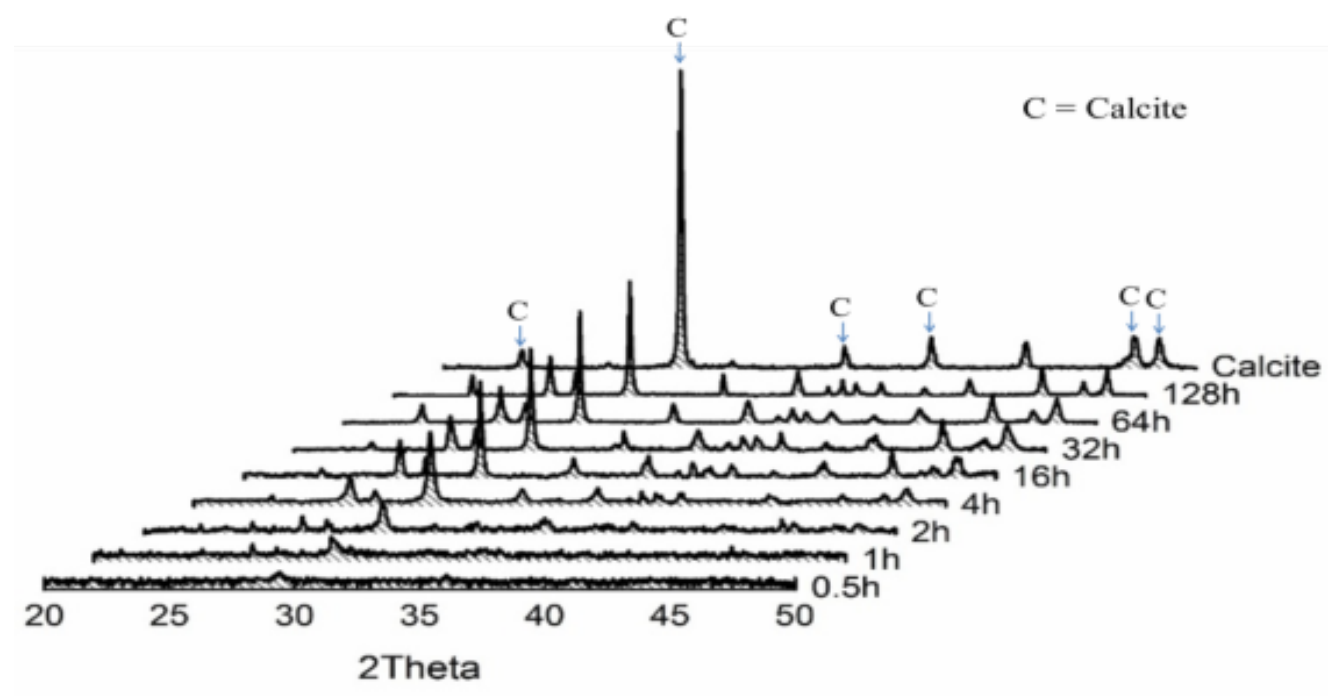

(a)

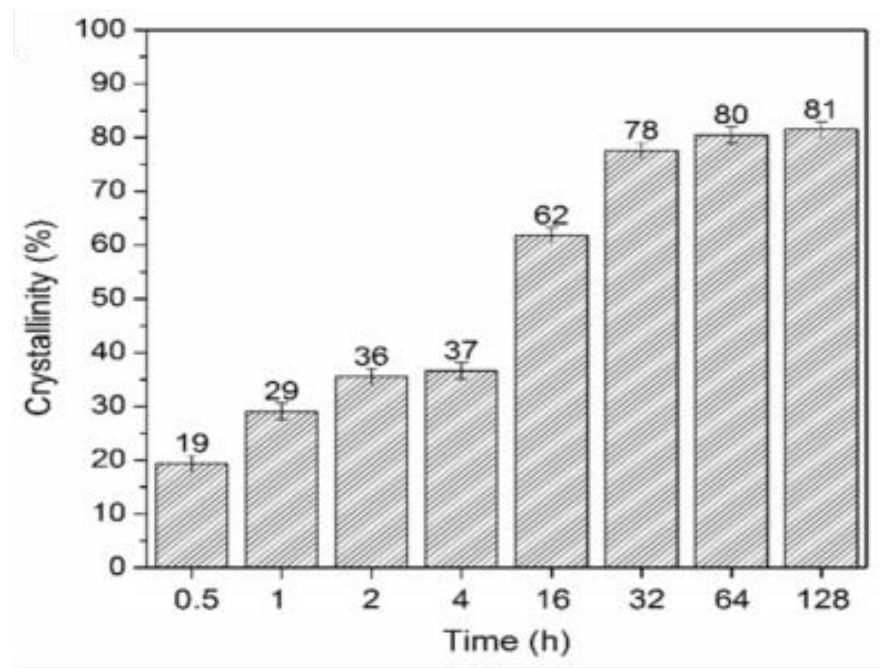

(b)

Figure 1. XRD pattern of precipitated calcite in the prepared bacterial solution(a), calculated crystallinity degree of $\mathrm{CaCO}_{3}$ (b)

We also adopted a semi-quantitative X-ray determination of crystallinity of $\mathrm{CaCO}_{3}$ crystal. There is an involvement of degree of crystallinity of the calcium carbonate during the incubation period of bacterial culture. After 64 hours, obtained result is equivalent to $80 \%$ of reference calcite mineral and staying stable result in the later period. The last one might be explained by the consequence of precipitated product that was generated on cell spores. Those outer layers prevent direct contact between microorganism, nutrient solution and oxygen source. It is also noted that oxygen is one of the most important factors to activate the bio-mineralization process of aerobic bacteria Bacillus subtilis[1].

Additionally, the result of FTIR spectrum of dried sample offered a clarification of material composition in bacterial solution. Figure 2 shows comparative results of the FTIR spectrums of 4 samples respectively after 1, 30, 60 and 90 days of incubation period. We recognized absorbance peaks of $\mathrm{CaCO}_{3}$ seen at different wave numbers of 712, 875, 1459 and $2519 \mathrm{~cm}^{-1}$ are recognized. 
Peaks at wave numbers 1798, 2880 and $2980 \mathrm{~cm}^{-1}$ correspond to $\mathrm{C}=\mathrm{O}$ bond in $\mathrm{CO}_{3}{ }^{2-}$ and peaks at wave numbers $1469 \mathrm{~cm}^{-1}$ probably correspond to $\mathrm{C}-\mathrm{O}$ bond in $\mathrm{CaCO}_{3}$. Those peaks allow us confirm the existing calcite product that was generated by Bacillus subtilis HU58. The peak absorbance of $\mathrm{N}-\mathrm{H}$ bond in urea nutrient with wave numbers of 556, 787 and $1590 \mathrm{~cm}^{-1}$ is minor in the final spectrum. Furthermore, $\mathrm{CaCl}_{2}$ in mixing nutrient could not be identified in Figure 2. It is presumably that the concentration of nutrient solution appears to be decreasing gradually due to bacteria metabolism. Last is also conforming to the above calculated result of degree of crystallinity.

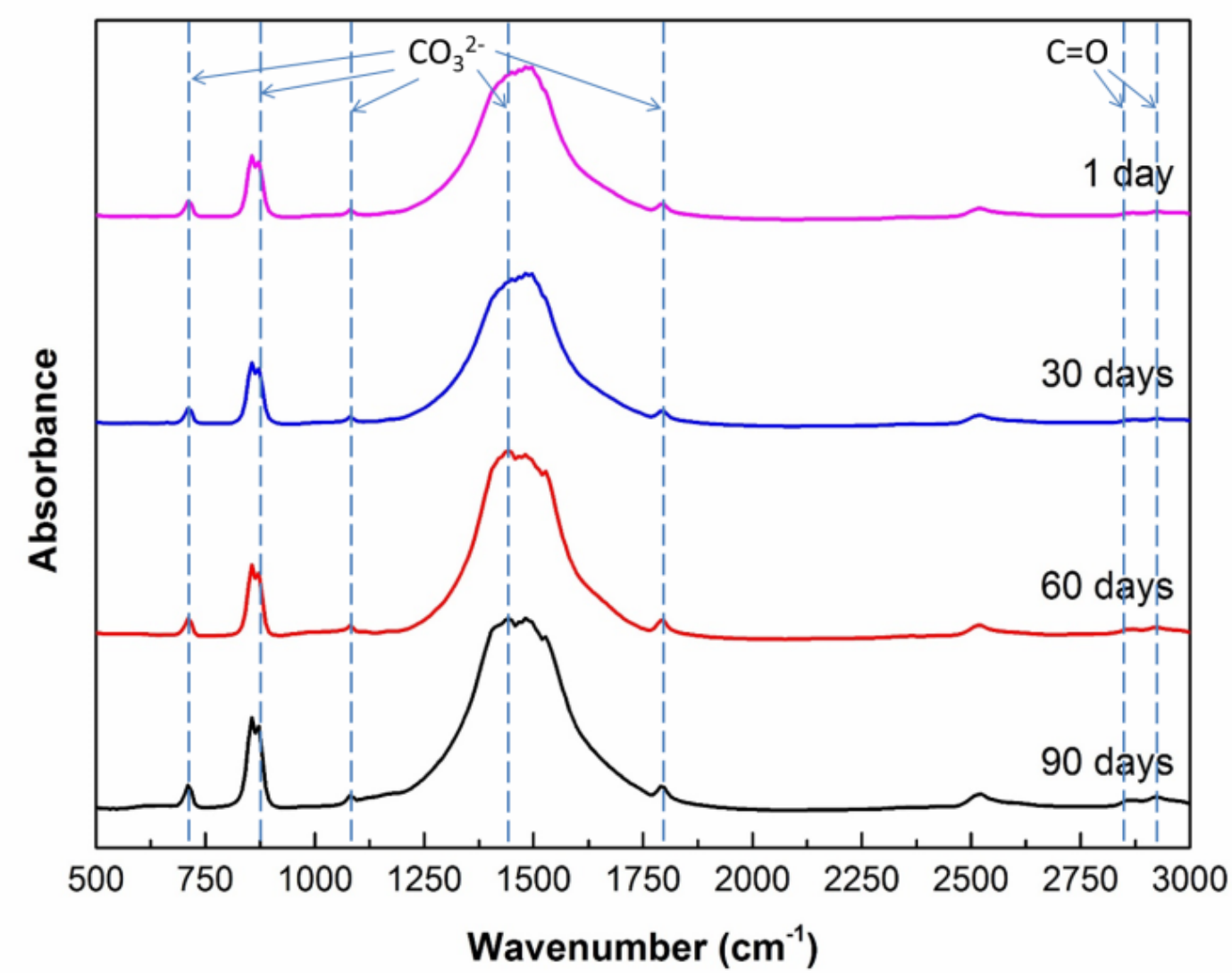

Figure 2. FTIR spectrum of bacterial solutions at 1, 30, 60 and 90 days of incubation period in Petri dish

In Figure 3, it is noted that bacteria cells (in dark color) were covered completely by rod-shaped crystals of precipitation product after 128 hours of incubation period. It seems that crystallography of calcium carbonate crystal is coincident with those observed in TEM image. Moreover, similar results of the bio-mineralization process of rod-shaped crystals were discussed in the previous study of V. Ramakrishnan using Bacillus pasteurii[9]. Others, they then dedicate themselves to continually enhancing compressive and flexural strength of mortar. They result from incorporation of deposited products of high concentrated microorganism that was enclosed with hardened mineral. Such explication was mentioned by V. Srinivasa Reddy in a study about the role of bacteria on global performance of self-healing concrete[10].

Basically, material modifications presumably included two facts of filling effect of crystallized mineral in meso pores and of autogenous micro-cracks in cement matrix due to self-healing ability. 

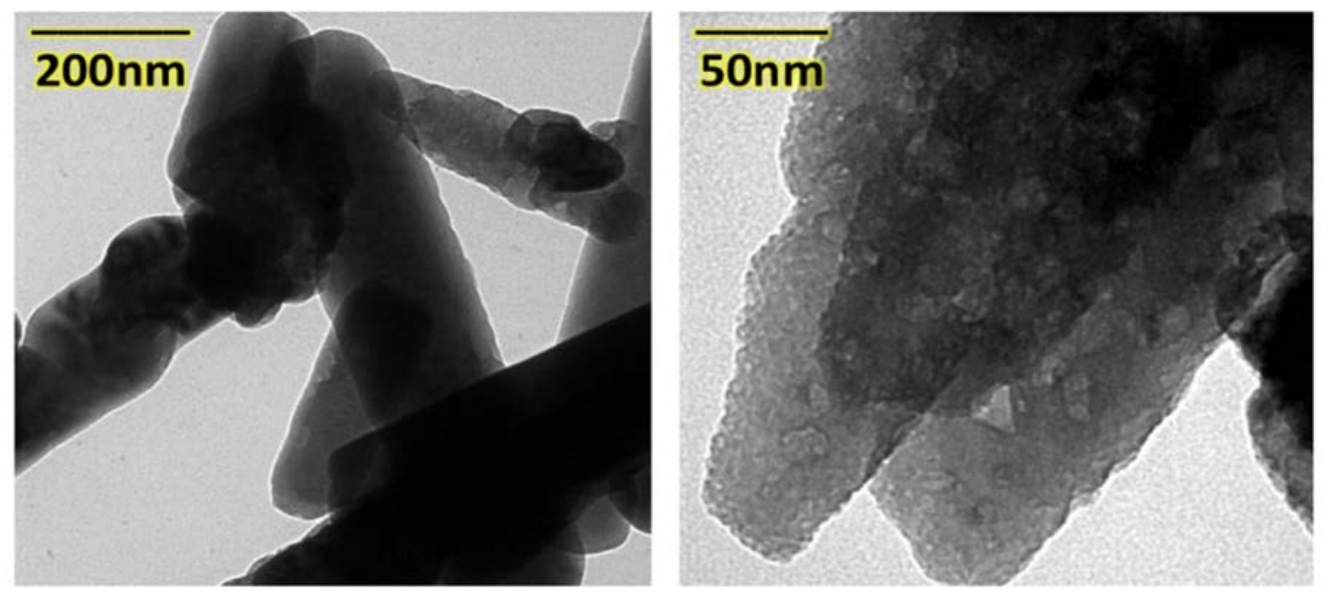

Figure 3. Morphological analysis by TEM of precipitated $\mathrm{CaCO}_{3}$ in the bacterial solution after 128 hours of incubation period

Figure 4 summarizes results of mechanical resistance of mortar sample. Obtained results of bacteria-modified mortar tend to increase gradually till the age of 1 year. Both compressive and flexural strength of bacteria-modified mortar are figured out higher value than controlled mortar (60 MPa in compression and $11 \mathrm{MPa}$ in flexion comparing with 56 $\mathrm{MPa}, 9 \mathrm{MPa}$ in case of controlled samples). Once again, it seems that we might associate the presence of calcite formed during the bio-mineralization process and such difference in resistance results. Moreover, by using Bacillus subtilis HU58 bacteria, we obtained better results (+36\% strength gain relative to controlled sample) of compressive strength than those mentioned in the previous study of P. Ghosh et al., [4] while using Shewanella anaerobic microorganism (+ $25 \%$ strength gain relative to controlled sample). A comparative study for flexural strength is impossible due to the lack of result published by Ghosh et al., but our obtained result is presumable explained by dotted fiber aggregate of calcite mineral in cement matrix.

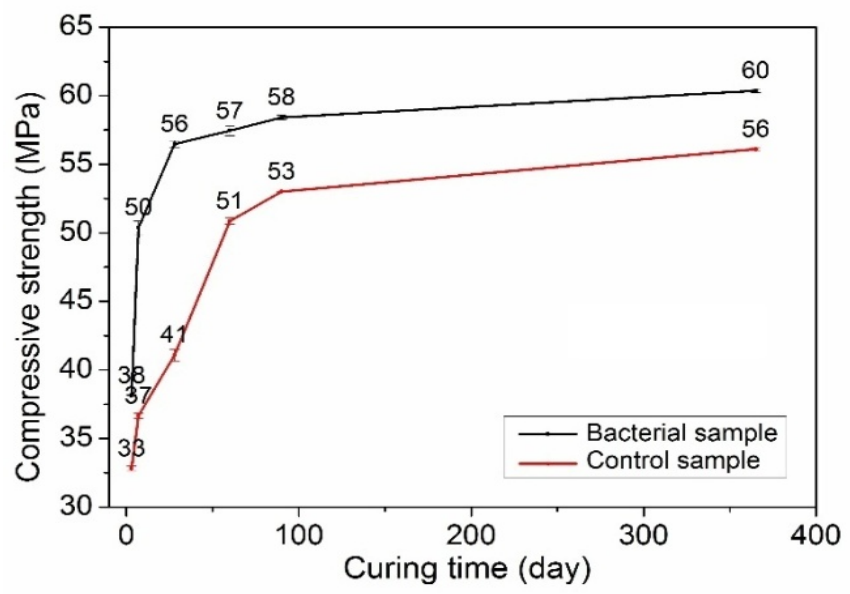

(a)

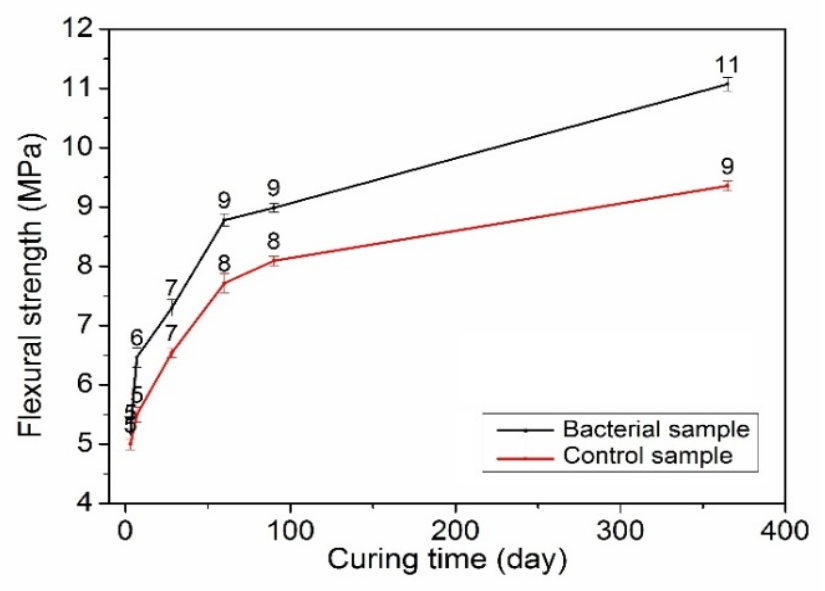

(b)

Figure 4. Strength development of cement mortar over different period of curing time: in compression (a) and in flexion (b) 

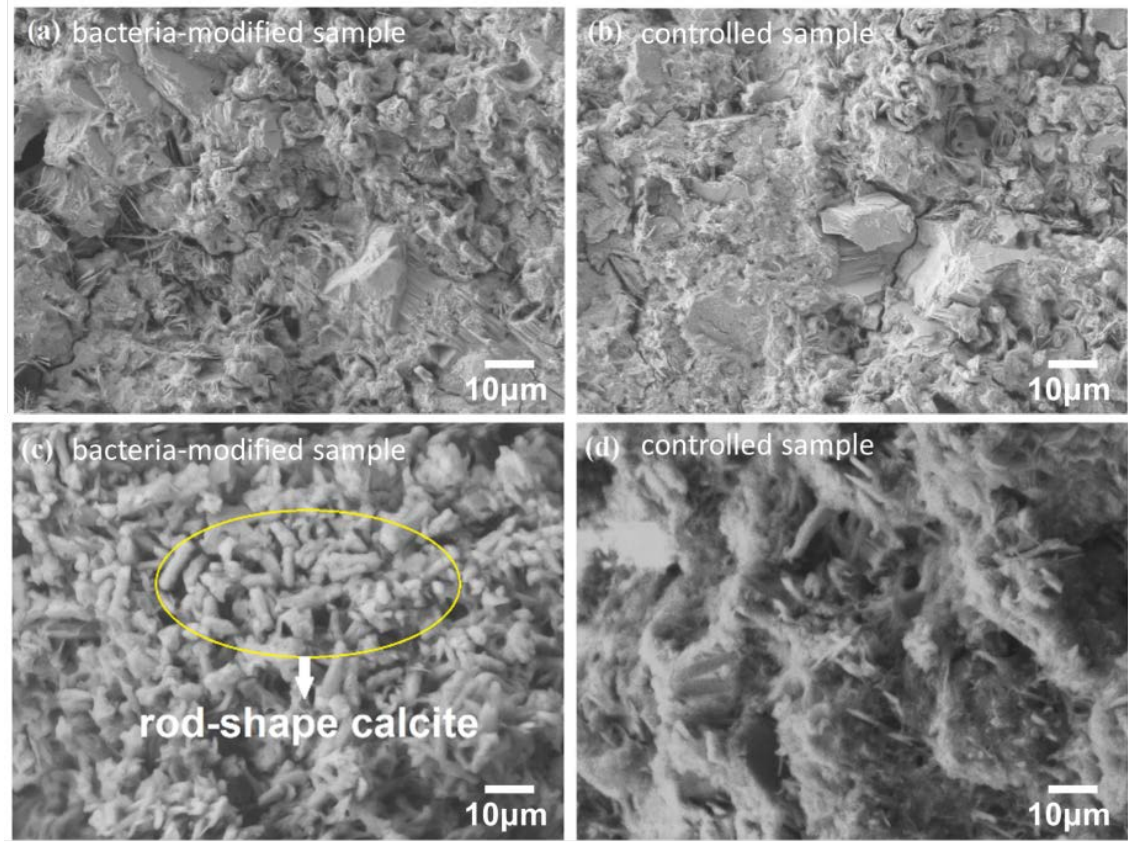

Figure 5. Microstructural illustration by SEM images of bacteria-modified mortar (a, c) and controlled sample (b, d) at the age of 1 year curing time

Figure 5 illustrates side by side the clichés of microstructure of bacterial and controlled mortar at the age of 1 year of curing time. We highlighted well-organized structure (figure $5 \mathrm{c})$, including a group of short rod-shaped calcite crystal $(0.9 \mu \mathrm{m}$ in length and $0.3 \mu \mathrm{m}$ in width).Similar results were mentioned in a study of $\mathrm{H}$. M. Jonkers $(3.7 \mu \mathrm{m}$ in length and $0.59 \mu \mathrm{m}$ in width, after 10 days of curing time) while last author used Bacillus pseudofirmus bacteria and nutrient solution containing yeast extract and peptone [11]. They contributed in general to make more compact microstructure of bacterial sample in comparison with controlled sample (Figure 5a, 5b). The later in turn tend to correlate in agreement with the increasing results of compressive and flexural strength of bacteriamodified mortar in Figure 4.
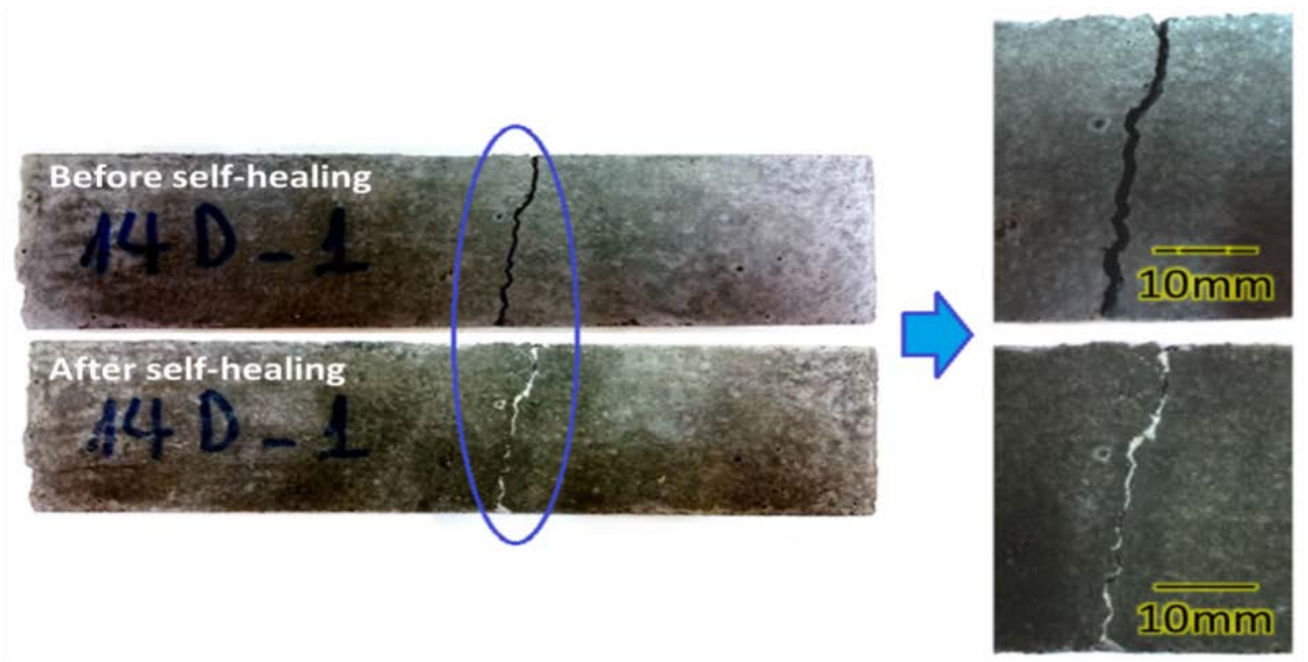

Figure 6. State of artificial crack of bacteria-modified mortar before and after self-healing test 
For the test of self-healing ability of bacterial sample, Figure 6 shows evolution of a1mm in width of artificial cracked (by using three-point flexural test) mortar prism. After 28 days of curing time, previous fracture position was marked with a white color track. The two parts of broken prismatic sample did not fall apart and thank to such white precipitated product to heal together. It is noted that $1 \mathrm{~mm}$ in width of artificial crack in this study is quite larger than $0.97 \mathrm{~mm}$ in width crack, investigated by J. Y. Wang [12] using Bacillus sphaericus LMG 22557. It is clear that the existing precipitated product act as mineral glue for self-healing issue.

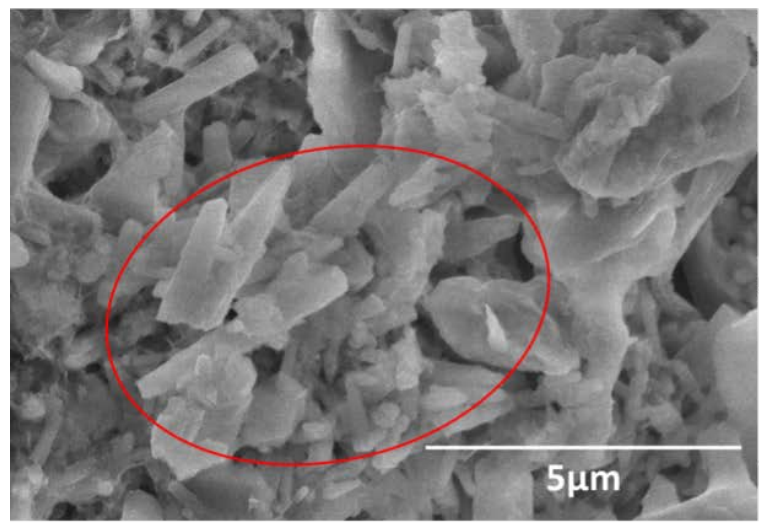

(a)

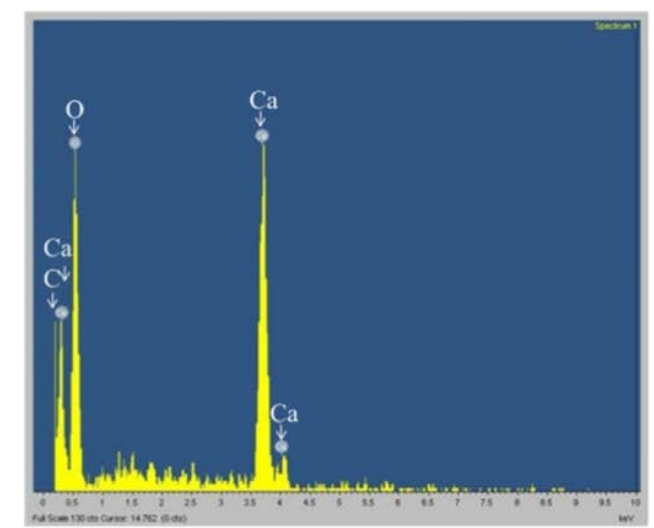

(b)

Figure 7. Result of SEM/EDX analysis of white precipitated product in healing fracture

Microstructure and composition of white color precipitated were characterized by SEM/EDX technique. We recognized in Figure 7 multiple group of coarse crystallized mineral. Result of EDX spectrum in figure 8shows relevant peaks of carbon, calcium and oxygen in their compositions. It means that artificial cracks were healed by precipitated calcium carbonate product due to active Bacillus subtilis HU58 bacteria in high humidity environment. This bio-mineralization process deposited precipitation products in both pores and open cracks until most remaining empty space in microstructure was filled up. Many factors such as bacteria type, quality and quantity of nutrient solution, curing condition could be envisaged to control this running process. Bacillus subtilis HU58 shows relevant result after 28 days of curing time in order to heal quite large open crack $1 \mathrm{~mm}$ in width.

\section{Conclusions}

Using bacterial solution that contains microbia Bacillus subtilis $\mathrm{HU} 58$, urea, $\mathrm{CaCl}_{2}$ and nutrient brot has an additive component in cement, pointed out positive effects on the global property of mortar. Bacteria-modified mortar after 1 year of curing time show nearly $7 \%$ and $22 \%$ higher in compressive strength and flexural strength while comparing to controlled sample without bacteria. Obtained results in this study are relatively better than previous studies using Shewanella and Bacillus pasteurii microbia. Precipitated product induced from the bio-mineralization process of Bacillus subtilis HU58 act as microbial sealant in consolidating mirco-cracks and pre-existing open cracks in damaged mortar. The morphology of crystallized calcite mineral is an important factor to enhance the material resistance. XRD, SEM/EDX analysis clarified the presence of carbonate calcium trace in 
open cracks and meso pores of hydrated cement matrix. The $1 \mathrm{~mm}$ in width artificial crack was filled completely by the abundant rod-shaped crystal in the self-healing test. Such evidence provides important information to investigate self-healing concrete at larger scale by using Bacillus subtilis HU58.

Acknowledgements: This research work is funded by Vietnam National University Ho Chi Minh City (VNU-HCM) under grant number C2016-20-29.

\section{References}

[1] A. Talaiekhozan, A. Keyvanfar, A. Shafaghat, R. Andalib, M.Z.Abd. Majid, M.A. Fulazzaky, R.M. Zin, C.T. Lee, M.W. Hussin, N. Hamzah, N.F. Marwar, and H.I. Haidar, "A review of self-healing concrete research development," Journal of Environmental Treatment Techniques, Vol. 2, No. 1, pp. 1-11, 2014.

[2] S. Ghosh, M. Biswas, B.D. Chattopadhyay, and S. Mandal, "Microbial activity on the microstructure of bacteria modified mortar," Cement and Concrete Composites, Vol. 31, No. 2, pp. 93-98, 2009.

[3] S.K. Ramachandran, V. Ramakrishnan, and S.S. Bang, "Remediation of concrete using microorganisms,” ACI Materials Journal, Vol. 98, No. 1, 2001.

[4] V. Wiktor, and H.M. Jonkers, "Quantification of crack-healing in novel bacteria-based self-healing concrete," Cement and Concrete Composites, Vol. 33, No. 7, pp. 763-770, 2011.

[5] S.M. Al-Thawadi, "Ureolytic bacteria and calcium carbonate formation as a mechanism of strength enhancement of sand," Journal of Advanced Science and Engineering Research, Vol. 1, No. 1, pp. 98-114, 2011.

[6] P. Ghosh, S. Mandal, B.D. Chattopadhyay, and S. Pal, "Use of microorganism to improve the strength of cement mortar," Cement and Concrete Research, Vol. 35, No. 10, pp. 1980-1983, 2005.

[7] N.N. Tri-Huynh, and N. Khanh-Son, "Use of bio-active Bacillus Subtilis Bacteria to form self-healing concrete," Science \& Technology Development, Vol. 17, No. 1K, pp. 76-86, 2014.

[8] International Organization for Standardization, Cement--test methods--determination of strength (ISO 679:2009), 2009, [Online]. Available: http://www.iso.org/iso/ catalogue_detail.htm?csnumber=45568 [Accessed: Nov, 2016].

[9] V. Ramakrishnan, R.K. Panchalan, S.S. Bang, and A. Khokhlova, "Improvement of concrete durability by bacterial mineral precipitation," Paper presented at the $11^{\text {th }}$ International Conference on Fracture (ICF11), Turin, Italy, March 2005.

[10] V.S. Reddy, K.A. Satya, S. Rao, and M. Azmatunnisa, “A biological approach to enhance strength and durability in concrete structures," International Journal of Advances in Engineering and Technology, Vol. 4, No. 2, 2012.

[11] H.M. Jonkers, "Self healing concrete: A biological approach,” In: Self Healing Materials, S. van der Zwagg, ed: Springer, Dordrecht, pp. 195-204, 2007.

[12] J.Y. Wang, H. Soens, W. Verstraete, and N. De Belie, "Self-healing concrete by use of microencapsulated bacterial spores," Cement and Concrete Research, Vol. 56, pp. 139-152, 2014. 